\title{
Ingestive behavior, ruminal and blood kinetics in lambs fed cow cheese whey
}

Comportamento ingestivo, cinéticas ruminal e sanguínea em ovinos alimentados com soro de queijo bovino

GUEDES $^{1 *}$, Luciana Freitas

https://orcid.org/0000-0002-5059-2011

PRIMO $^{2}$, Tatiana Santos

https://orcid.org/0000-0002-9773-7740

VASCONCELOS ${ }^{2}$, Ângela Maria de https://orcid.org/0000-0002-9690-974X

POMPEU ${ }^{1}$, Roberto Cláudio Fernandes Franco

https://orcid.org/0000-0002-4099-3575

\author{
NEIVA 3 , José Neuman Miranda \\ https://orcid.org/0000-0001-7817-8210
}

$\operatorname{COSTA}^{4}$, Clésio dos Santos

https://orcid.org/0000-0003-0451-7157

OLIVEIRA $^{2}$, Delano de Sousa

https://orcid.org/0000-0002-1960-335X

ROGÉRIO ${ }^{1}$, Marcos Cláudio Pinheiro https://orcid.org/0000-0003-3567-5211

${ }^{1}$ Embrapa Caprinos e Ovinos, Laboratório de Respirometria do Semiárido, Sobral, Ceará, Brasil. ${ }^{2}$ Universidade Estadual Vale do Acaraú, Departamento de Zootecnia, Sobral, Ceará, Brasil

${ }^{3}$ Universidade Federal do Tocantins, Departamento de Zootecnia, Araguaína, Tocantins, Brasil

${ }^{4}$ Universidade Federal do Ceará, Departamento de Zootecnia, Fortaleza, Ceará, Brasil

*Corresponding author: lucianafguedes@gmail.com

\begin{abstract}
The objective of this study was to evaluate the inclusion of cow cheese whey (CCW) in the diet for lambs on the ingestive behavior, ruminal and blood parameters. Twenty crossbred, male, non-castrated lambs with $25 \mathrm{~kg}$ body weight were assigned to four treatments: control diet (composed of corn, soybean meal and native pasture silage) and test diets (control diet + inclusion of $\mathrm{CCW}$ in increasing levels of 1.6, 2.7 and $4.0 \%$ in $\mathrm{DM})$, in a completely randomized design with four treatments and five replications. Means were compared by Tukey's test, and the strength of association between variables was tested by Pearson's correlation. Regression analysis was also performed for data from the collection of ruminal fluid and blood. Behavioral assessments were made at a 24-hour interval in measurements taken every five minutes. The inclusion of CCW in the diet did not impair ruminal $\mathrm{pH}$, but promoted a decrease in rumination and feeding times, also causing a lower number of cuds and a lower number of cud chews. The lowest concentration of ammonia nitrogen and total protein were found in lambs receiving the diet with 4\% CCW. However, these values were within the range recommended for microbial growth. $\mathrm{CCW}$ is a potential protein alternative in lambs feed as it does not interfere with nutrient intake, ruminal and blood parameters, and favors a positive nitrogen balance.
\end{abstract}

Key words: feedlot, diet, rumination, by-product 


\section{RESUMO}

Objetivou-se avaliar a inclusão de soro de queijo bovino (SQB) na dieta para ovinos sobre o comportamento ingestivo, os parâmetros ruminais e sanguíneos. Vinte ovinos mestiços, machos, não castrados, com $25 \mathrm{~kg}$ de peso corporal foram distribuídos em quatro dietas: dieta controle (composta por milho, farelo de soja e silagem de pasto nativo) e as dietas teste (dieta controle + inclusão de SQB em níveis crescentes 1,6; 2,7 e 4,0\% na MS), em um delineamento inteiramente ao acaso com quatro tratamentos e cinco repetições. A comparação de médias foi realizada pelo teste Tukey e foram testadas as correlações de Pearson entre as variáveis. Também foi feita a análise de regressão para os dados provenientes da coleta de líquido ruminal e de sangue. As avaliações de comportamento foram feitas em um intervalo de 24 horas em medições realizadas a cada cinco minutos. A inclusão de SQB na dieta não comprometeu o $\mathrm{pH}$ ruminal, mas promoveu a queda nos tempos de ruminação e de alimentação, ocasionando também menor número de bolos ruminais e menor número de mastigações merícicas. A menor concentração de nitrogênio amoniacal e proteínas totais foram encontradas nos ovinos que receberam a dieta com $4 \%$ de inclusão de SQB. Entretanto, esses valores ficaram dentro do padrão estabelecido para crescimento microbiano. O SQB é uma potencial alternativa proteica na alimentação de ovinos por não interferir no consumo de nutrientes, nos parâmetros ruminais e sanguíneos, e favorecer o balanço positivo de nitrogênio.

Palavras-chave: confinamento, dieta, ruminação, subproduto

\section{INTRODUCTION}

The seasonality of rainfall in the Northeast of Brazil reduces the quality and availability of forages and grains, which in turn affect the production indices of herds, which implies an increase in costs related to feeding. Thus, the use of by-products to feed ruminants with nutritional quality can contribute to improve the efficiency of production systems in the northeastern semiarid.

In this condition, cow cheese whey (CCW) is considered a potential food alternative, with wide availability, high acceptability by animals and is made up of proteins of high biological value (DAVID et al., 2010). The annual national production of CCW is estimated at 500 thousand tons, on average, however the use of this by-product reaches only $15 \%$ of the total whey produced, being considered a high-grade pollutant (PRAZERES et al., 2012).
Therefore, $\mathrm{CCW}$ is a by-product of high nutritional potential, but a large part is disposed in the environment.

When evaluating alternative feeds for animals, dry matter intake and nutrient digestibility important parameters to determine the nutritional value of the food. However, the study of ingestive behavior is essential and complementary, as it allows the adjustment of food management of the animals according to the characteristics of the food and the nictemeral pattern and, thus, seeks the best productive performance according to the diet provided. In general, the periods spent with food intake are interspersed with one or more periods of rumination or idleness, and the time spent on rumination is usually longer at night, being mainly controlled by the nature of the diet. In addition, the assessment of ruminal fluid $\mathrm{pH}$ is an important parameter because it is correlated to the 
final fermentation products as well as the growth rate of rumen microorganisms, so that it can decline with fiber restriction in the diet or by the addition of rapidly fermentable carbohydrates (VAN SOEST, 1994).

Thus, the objective was to evaluate increasing levels of cow cheese whey in lambs diets on the intake and digestibility of nutrients, ingestive behavior and ruminal and blood parameters.

\section{MATERIAL AND METHODS}

The experiment was carried out at the Research Center for Nutrition of Small Ruminants at the Vale do Acarau Experimental Farm, belonging to the Vale do Acarau State University - UVA, in Sobral, state of Ceará, at 3036' South latitude, $40^{\circ} 18^{\prime}$ 'West longitude, $56 \mathrm{~m}$. The region has a BSh (Köppen classification), megathermal, dry climate, with average rainfall (February to May) of $888.9 \mathrm{~mm}$, corresponding to $92.6 \%$ of the average annual total. The average annual temperature is $26.6{ }^{\circ} \mathrm{C}$ and the average relative humidity is $67.9 \%$.
Twenty crossbred, non-castrated, male lambs, five months of age, average body weight of $25 \mathrm{~kg}$, were weighed, dewormed and individually housed in metabolic cages. The control diet consisted of corn, soybean meal and siratro silage (Macroptilium atropurpureum DC. cv. Siratro) with native Caatinga pasture containing: vassourinha-de-botão (Borreria verticillata G.F.W. Mayer), climbing dayflower (Commelina diffusa Burnm.F), jetirana (Merremia aegyptia), malva-branca (Sida cordifolia), capimmilhã (Brachiaria spp.; Panicum spp.; Setaria spp) and pinto peanut (Arachis pintoi). Test diets were composed of the same ingredients with inclusion of cow cheese whey $(\mathrm{CCW})$ at increasing levels (1.6; 2.7 and 4.0\% in DM) (Tables 1 and 2). Diets were formulated according to the nutritional requirements of finishing lambs, with four months of age, $20 \mathrm{~kg}$ body weight and gain of $200 \mathrm{~g} \mathrm{day}^{-1}$, based on the NRC (2007), establishing average food leftovers of $10-15 \%$ of the total provided in DM. Diets were supplied to the lambs at eight and at 17 hours. Mineral salt and water were available at will. 
Table 1. Chemical composition (\%) of feed supplied during the experimental period.

\begin{tabular}{|c|c|c|c|c|c|}
\hline Component (\%DM*) & $\begin{array}{c}\text { Pasture } \\
\text { silage }\end{array}$ & $\mathrm{CCW}$ & Corn & $\begin{array}{c}\text { Soybean } \\
\text { meal }\end{array}$ & $\begin{array}{c}\text { Limeston } \\
\mathrm{e}\end{array}$ \\
\hline Dry matter ${ }^{\#}$ & 27.58 & 6.78 & 89.36 & 89.65 & 100.00 \\
\hline Crude protein & 8.96 & 18.30 & 10.33 & 53.56 & - \\
\hline Ether extract & 1.26 & 7.37 & 3.48 & 4.30 & - \\
\hline Neutral detergent fiber & 76.17 & - & 29.63 & 43.43 & - \\
\hline Acid detergent fiber & 50.78 & - & 6.09 & 11.27 & - \\
\hline Cellulose & 35.34 & - & 4.04 & 9.87 & - \\
\hline Lignin & 10.40 & - & 0.68 & 1.56 & - \\
\hline Mineral matter & 12.73 & 0.89 & 1.17 & 0.43 & - \\
\hline Calcium & 1.74 & 0.43 & 0.85 & 0.82 & 38.00 \\
\hline Phosphorus & 0.52 & 0.03 & 0.28 & 0.77 & - \\
\hline Total carbohydrates & 77.05 & 73.44 & 85.02 & 35.91 & - \\
\hline Non-fiber carbohydrates & 5.63 & 73.44 & 55.83 & 11.23 & - \\
\hline TDN & 44.15 & 97.60 & 77.41 & 62.61 & - \\
\hline
\end{tabular}

*DM $=$ Dry matter; $\mathrm{CCW}=$ cow cheese whey; $\mathrm{TDN}=$ Total digestible nutrients, according to NRC (2001). \#in \% natural matter.

Table 2. Proximate and chemical composition of diets (\%) containing increasing levels of cow cheese whey (CCW) for finishing lambs.

\begin{tabular}{cccccc}
\hline \multicolumn{5}{c}{ Proximate composition of the diets (\%natural matter) } \\
\hline $\begin{array}{c}\text { CCW } \\
\text { inclusion } \\
(\% \mathrm{MS})\end{array}$ & $\begin{array}{c}\text { Native } \\
\text { pasture silage }\end{array}$ & $\mathrm{CCW}$ & Corn & $\begin{array}{c}\text { Soybean } \\
\text { meal }\end{array}$ & Limestone \\
\hline 0 & 73.41 & 0.00 & 17.62 & 8.71 & 0.27 \\
1.6 & 64.79 & 10.17 & 16.94 & 7.87 & 0.23 \\
2.7 & 56.83 & 18.25 & 16.76 & 7.91 & 0.26 \\
4.0 & 49.00 & 26.05 & 17.18 & 7.46 & 0.31 \\
\hline \multicolumn{5}{c}{ Chemical composition of experimental diets } \\
\hline Component (\% DM) & 0 & 1.6 & 2.7 & 4.0 \\
\hline Dry matter & & 44.07 & 40.98 & 39.24 & 36.63 \\
Crude protein & 13.06 & 13.63 & 14.40 & 14.93 \\
Ether extract & 1.91 & 2.49 & 2.98 & 3.46 \\
Neutral detergent fiber & 64.92 & 57.79 & 51.69 & 45.65 \\
Acid detergent fiber & 39.33 & 34.82 & 30.77 & 26.77 \\
Cellulose & 27.51 & 24.36 & 21.54 & 18.75 \\
Lignin & 7.89 & 6.98 & 6.15 & 5.33 \\
Mineral matter & 10.09 & 9.03 & 8.09 & 7.14 \\
Calcium & 1.60 & 1.47 & 1.37 & 1.29 \\
Phosphorus & 0.50 & 0.45 & 0.41 & 0.37 \\
Total carbohydrates & 74.67 & 74.61 & 74.28 & 74.17 \\
Non-fiber carbohydrates & 14.95 & 21.46 & 26.85 & 32.32 \\
TDN & 61.65 & 63.61 & 67.14 & 68.75 \\
\hline
\end{tabular}

*DM $=$ Dry matter; TDN $=$ Total digestible nutrients, according to NRC (2001). \#in \% natural matter. 
The experiment lasted 30 days with 23 days for adaptation and seven days for data collection (intake and digestibility test, collection of ruminal fluid and blood, and ingestive behavior assessments). Samples of the offered diet, leftovers, urine and feces were collected daily, weighed, packed in plastic bags and refrigerated at $-10^{\circ} \mathrm{C}$ ). Subsequently, samples were thawed at room temperature to make a composite sample of the seven days per animal, and taken to a forced ventilation oven at 55 ${ }^{\circ} \mathrm{C}$ for 72 hours. Soon after, they were ground through a $1 \mathrm{~mm}$ sieve and reserved for analysis.

Chemical composition was determined at the Animal Nutrition Laboratory of UVA. The methodology proposed by AOAC (2010) was followed for determinations of dry matter (DM), organic matter (MO) and mineral matter $(\mathrm{MM})$, ether extract (EE) and crude protein $(\mathrm{CP})$ of the material. In turn, the methodology of Van Soest et al. (1991) was used for quantification of fiber portions, neutral detergent fiber (NDF), acid detergent fiber (ADF), lignin and cellulose.

Total digestible nutrients (TDN) of foods was estimated according to equations of Cappelle et al. (2001). For calculation of TDN of experimental diets, the equation of NRC (2001) was used. Non-fiber carbohydrates (NFC) was estimated according to Weiss (1999). Calculations of digestibility coefficients of DM, OM, $\mathrm{CP}$ and NDF were determined by the formula [(Nutrient ingested (g) - Amount of nutrients in feces $(\mathrm{g})$ ) / Nutrient intake (g)] x 100.

Ruminal fluid was collected by esophageal tube for the measurements of ruminal $\mathrm{pH}$ and ammonia nitrogen $\left(\mathrm{NH}_{3}-\right.$ $\mathrm{N})$ at four pre-established times $(0,3,6$ and $9 \mathrm{~h}$ postprandial). The $\mathrm{pH}$ was measured in a Micronal B271 ${ }^{\circledR}$ potentiometer, immediately after the collection of the ruminal fluid, while the samples with $50 \mathrm{~mL}$ ruminal fluid were acidified in $1 \mathrm{~mL}$ sulfuric acid 1: 1 and stored at $-5{ }^{\circ} \mathrm{C}$ to determine $\mathrm{NH}_{3}-\mathrm{N}$, by distillation with magnesium oxide, at the Animal Nutrition Laboratory of UVA.

Blood was drawn by puncture of the jugular vein to determine serum levels of urea and total proteins, at the times established for the collection of ruminal fluid. Serum analyses were performed using Bioclin ${ }^{\circledR}$ kits, at the Animal Nutrition Laboratory of UVA and at the Bromatology Laboratory of the Federal Institute of Education, Science and Technology of Ceara (IFCE - Sobral Campus).

Ingestive behavior was evaluated during 24 hours with time spent on feeding (TA), rumination (TR), idle (TO) and other activities, adopting the visual observation of the animals every five minutes according to Johnson and Combs (1991), using a digital stopwatch. In the night observation, the environment was maintained with artificial lighting. Ingestive behavior variables were obtained from the ratios: ERMS = $\mathrm{CMS} / \mathrm{TRU} ; \mathrm{ERFDN}=\mathrm{CFDN} / \mathrm{TRU}$; $\mathrm{TMT}=\mathrm{TAL}+\mathrm{TRU} ; \mathrm{tMMb}=\mathrm{BOL} / \mathrm{MMb}$, where: $\mathrm{ERMS}=$ rumination efficiency in grams of dry matter/hour; CMS = dry matter intake in grams; TRU = rumination time in hours/day; ERFDN = rumination efficiency in grams of neutral detergent fiber/hour; CFDN = neutral detergent fiber intake in grams; TMT = total chewing time in hours/day; TAL = feeding time in hours/day; $\mathrm{tMMb}=$ time of cud chews per cud in seconds/cud; $\mathrm{BOL}=$ number of cuds/day, considering cud as the portion of food that returns to 
the mouth to be chewed for the second time (Polli et al., 1996); $\mathrm{MMb}=$ number of cud chews per cud.

Data were initially subjected to normality (Crame-Von Misses) and homoscedasticity (Levene) tests; when the assumptions were met, an analysis of variance was applied using the F-test. In case of significant differences, means were compared by SNK test at 5\% probability level. Statistical analyses were run using the GLM procedure of SAS 9.0 software (2002).

Data on intake, digestibility and behavior were analyzed in a completely randomized design with four treatments (inclusion of $\mathrm{CCW}$ ) and five replications, according to the statistical model:

Where:

$$
\mathrm{Y}_{\mathrm{ij}}=\mu+\mathrm{H}_{\mathrm{j}}+\mathrm{e}_{\mathrm{ij}}
$$

$Y_{i j}=$ value referring to the observation of repetition $i$ of treatment $j$;

$\mu=$ overall mean;

$\mathrm{H}_{\mathrm{j}}=$ effect of treatment $\mathrm{j}$ ( $\mathrm{j}=$ zero; 1.6 ;

$2.7 ; 4.0)$;

$\mathrm{e}_{\mathrm{ij}}=$ random error associated with the observation.
Data on ruminal fluid and blood were analyzed in a completely randomized design, in a split-plot arrangement, with the treatments (inclusion of CCW) in the plots, and the collection times in the subplots, with four replications, according to the statistical model:

Yijk $=\mu+$ Fj + Tk + FTjk + eijk

Where:

Yijk = value referring to the observation of repetition $\mathrm{i}$ in treatment $\mathrm{j}$ and in collection time $\mathrm{k}$;

$\mu=$ overall mean;

$\mathrm{Fj}=$ effect of treatment $\mathrm{j}(\mathrm{j}=$ zero, $1.6 \%$, $2.7 \%, 4.0 \%$ );

$\mathrm{Tk}=$ effect of the collection time $\mathrm{k}(\mathrm{k}=$ zero, 3, 6, 9);

FTjk = interaction of the effects of treatment $\mathrm{j}$ with collection time $\mathrm{k}$;

eijk $=$ random error associated with the observation.

\section{RESULTS AND DISCUSSION}

The inclusion of CCW in a lambs diet did not influence the intake and digestibility of nutrients, except ( $p$ $<0.05$ ) for the intake of the fiber portion of the diet (Table 3 ). 
Table 3. Intake of dry matter, organic matter, crude protein, ether extract and digestible fractions of lambs diets containing increasing levels of cow cheese whey (CCW).

\begin{tabular}{|c|c|c|c|c|c|}
\hline \multirow{2}{*}{ Component } & \multicolumn{4}{|c|}{$\mathrm{CCW}$ inclusion $(\% \mathrm{DM})$} & \multirow{2}{*}{$\mathrm{CV}(\%)$} \\
\hline & 0 & 1.6 & 2.7 & 4.0 & \\
\hline \multicolumn{6}{|c|}{ Nutrient intake (grams per unit of metabolic size) } \\
\hline Dry matter $(\mathrm{g} / \mathrm{UTM})$ & 111.75 & 109.14 & 101.26 & 104.36 & 10.63 \\
\hline Dry matter (g/day) & $1345.25^{\mathrm{b}}$ & $1360.70^{\mathrm{a}}$ & $1158.64^{\mathrm{d}}$ & $1309.43^{c}$ & 18.01 \\
\hline Organic matter (g/UTM) & 95.49 & 91.72 & 83.57 & 84.69 & 10.84 \\
\hline Organic matter (g/day) & $1149.83^{\mathrm{a}}$ & $1143.78^{\mathrm{a}}$ & $956.04^{\mathrm{b}}$ & $1062.23^{\mathrm{a}}$ & 18.09 \\
\hline Crude protein (g/UTM) & 20.05 & 19.59 & 18.78 & 18.79 & 11.70 \\
\hline Crude protein (g/day) & 239.57 & 244.01 & 214.56 & 234.98 & 16.64 \\
\hline Ether extract (g/UTM) & 2.98 & 3.01 & 2.86 & 2.94 & 12.85 \\
\hline Ether extract (g/day) & 35.84 & 37.49 & 32.72 & 36.45 & 16.64 \\
\hline $\begin{array}{l}\text { Neutral detergent fiber } \\
(\mathrm{g} / \mathrm{UTM})\end{array}$ & $57.46^{\mathrm{a}}$ & $52.76^{\mathrm{ab}}$ & $46.27^{\mathrm{b}}$ & $46.04^{\mathrm{b}}$ & 11.20 \\
\hline $\begin{array}{l}\text { Neutral detergent fiber } \\
\text { (g/day) }\end{array}$ & $692.36^{\mathrm{a}}$ & $657.89^{\mathrm{ab}}$ & $529.10^{c}$ & $579.11^{\mathrm{bc}}$ & 18.63 \\
\hline $\begin{array}{l}\text { Non-fiber carbohydrates } \\
\text { (g/day) }\end{array}$ & $261.72^{\mathrm{b}}$ & $305.25^{\mathrm{ab}}$ & $286.01^{\mathrm{ab}}$ & $355.10^{\mathrm{a}}$ & 19.55 \\
\hline \multicolumn{6}{|c|}{ Nutrient digestibility (\%) } \\
\hline Dry matter & 64.76 & 65.02 & 68.06 & 68.25 & 7.56 \\
\hline Organic matter & 67.11 & 66.97 & 69.25 & 68.91 & 7.25 \\
\hline Crude protein & 66.52 & 66.05 & 66.24 & 65.81 & 8.06 \\
\hline Ether extract & 76.89 & 79.27 & 77.35 & 80.75 & 7.60 \\
\hline Neutral detergent fiber & 46.18 & 43.26 & 41.38 & 39.11 & 18.44 \\
\hline
\end{tabular}

Mean values followed by different letters, in the same row, are significantly different by SNK test $(\mathrm{P}<0.05)$.

The inclusion of CCW favored the intake of NFC (Table 3), which corresponds to the higher intake of components of fractions A (soluble sugars and rapidly degraded organic acids) and B1 (starch, pectin and glucans). These components are rapidly fermented, providing readily available energy for ruminal microorganisms (WEISS et al., 1999). In addition, the inclusion provided a positive nitrogen balance due to the effect of protein on digestion and microbial fermentation (Table 4). 
Table 4. Nitrogen balance in lambs fed increasing levels of cow cheese whey (CCW) in the diet.

\begin{tabular}{lccccc}
\hline \multirow{1}{*}{ Parameter } & \multicolumn{3}{c}{ CCW inclusion (\% DM) } & \multirow{2}{*}{ CV (\%) } \\
& 0 & 1.6 & 2.7 & 4.0 & \\
\hline Ingested nitrogen (g/day) & 38.33 & 39.04 & 34.33 & 37.59 & 16.64 \\
Fecal nitrogen (g/day) & 12.85 & 13.27 & 11.57 & 12.71 & 22.16 \\
Urinary nitrogen (g/day) & 6.17 & 7.17 & 6.56 & 5.24 & 41.28 \\
Nitrogen balance & 19.30 & 18.60 & 16.19 & 19.64 & 30.82 \\
Retained nitrogen (\% ingested & 49.76 & 47.66 & 47.46 & 50.65 & 22.28 \\
N) & & & &
\end{tabular}

Mean values followed by different letters, in the same row, are significantly different by SNK test $(\mathrm{P}<0.05)$.

Araujo (2012) tested similar levels of inclusion of CCW in diets for goats and reported that the use of CCW does not affect the use of nitrogen and guarantees sufficient nitrogen for physiological and reserve functions, which reflects this positive nitrogen balance.

Higher levels of CCW (2.7 and 4.0\%) promoted lower TR and TA and higher TO $(\mathrm{P}<0.05)$, and the time with other activities was not influenced $(\mathrm{P}>0.05)$ by SQB in diet (Table 5).

Table 5. Time spent with rumination, feeding, other activities and idle (hours) of lambs fed increasing levels of cow cheese whey $(\mathrm{CCW})$ in the diet.

\begin{tabular}{lccccc}
\hline \multirow{2}{*}{ Parameter (hours) } & \multicolumn{5}{c}{ CCW inclusion (\% DM) } \\
& 0 & 1.6 & 2.7 & \multirow{2}{*}{ CV\% } \\
\hline Rumination time & $7.72^{\mathrm{a}}$ & $7.56^{\mathrm{a}}$ & $6.96^{\mathrm{ab}}$ & $5.68^{\mathrm{b}}$ & 20.64 \\
Feeding time & $4.39^{\mathrm{ab}}$ & $4.60^{\mathrm{a}}$ & $3.50^{\mathrm{bc}}$ & $3.42^{\mathrm{c}}$ & 25.00 \\
Idle time & $11.12^{\mathrm{bc}}$ & $10.68^{\mathrm{c}}$ & $12.94^{\mathrm{ab}}$ & $13.68^{\mathrm{a}}$ & 18.99 \\
Other activities & 0.80 & 1.16 & 0.60 & 1.22 & 66.11 \\
\hline
\end{tabular}

Mean values followed by different letters, in the same row, are significantly different by SNK test $(\mathrm{P}<0.05)$.

The periods spent with food intake are interspersed with one or more periods of rumination or idleness, and the periods of rumination are controlled by the type of food, rising with a greater forage: concentrate ratio. Fiber requires more time in the digestion and rumination process, and thus greater amounts of NDF in the diet decrease the rate of passage through the digestive tract of the ruminant (CHURCH, 1979). Thus, the shorter feeding and rumination time is justified with the increasing inclusion of $\mathrm{CCW}$ as a result of lower NDF intake and higher NFC intake (Table 3).

As a consequence, the diet with inclusion of CCW by $4 \%$ indicated lower BOL (P $<0.05)$ with a high correlation between the intake of NDF $(\mathrm{g} / \mathrm{UTM})$ and BOL $(\mathrm{r}$ $=0.777623 ; \mathrm{P}<0.0001)$, so that smaller amounts of NDF implies less BOL due to a smaller stimulus to chewing activity. However, the use of CCW did not interfere with the other parameters (FE, ERMS, ERFDN, TMT, MMb and $\mathrm{tMMb}$ ), which shows the potential of this by-product in lambs feed (Table 6). 
Table 6. Feed efficiency (FE), rumination efficiency in grams of DM/hour (ERMS) and in grams of NDF/hour (ERFDN), total chewing time (TMT in hours/day), number of daily cuds (BOL), chews per cud (MMb), time of chews per cud (tMMb in seconds/cud) in lambs fed increasing levels of cow cheese whey $(\mathrm{CCW})$ in the diet.

\begin{tabular}{lccccc}
\hline \multirow{2}{*}{ Component } & 0 & \multicolumn{5}{c}{ CCW inclusion (\% DM) } & \multirow{2}{*}{ (\%) } \\
\hline FE & 339.22 & 301.32 & 334.63 & 407.41 & 31.85 \\
ERMS & 179.22 & 179.67 & 174.41 & 234.86 & 21.99 \\
ERFDN & 92.30 & 86.88 & 79.54 & 103.92 & 23.03 \\
TMT & 12.11 & 12.16 & 10.46 & 9.10 & 18.65 \\
BOL & $44.64^{\mathrm{a}}$ & $39.30^{\mathrm{a}}$ & $36.27^{\mathrm{a}}$ & $23.59^{\mathrm{b}}$ & 17.36 \\
$\mathrm{MMb}$ & 154.17 & 124.89 & 170.20 & 162.47 & 19.65 \\
tMMb & 98.59 & 106.65 & 112.16 & 106.13 & 15.23 \\
\hline
\end{tabular}

Mean values followed by different letters, in the same row, are significantly different by SNK test $(\mathrm{P}<0.05)$.

There was no interaction $(\mathrm{P}>0.05)$ between the inclusion of $\mathrm{CCW}$ and the collection times for $\mathrm{NH}_{3}-\mathrm{N}$, ruminal $\mathrm{pH}$, serum urea and total proteins (Table 7). However, inclusion with $4 \% \mathrm{CCW}$ showed lower $\mathrm{NH}_{3}-\mathrm{N}$. The higher intake of NFC with $4 \% \mathrm{CCW}$ may have led to greater microbial protein synthesis, reducing the concentration of $\mathrm{NH}_{3}-\mathrm{N}$ in the rumen fluid. At the same time, the increasing inclusion of CCW may have favored ruminal fermentation, since $\mathrm{CCW}$ proteins have high nutritional value, high content of essential amino acids, especially branched chain (COSTA et al., 2010). The concentrations of $\mathrm{NH}_{3}-\mathrm{N}$ were within the range for an adequate microbial fermentation $(>10 \mathrm{mg} / 100 \mathrm{~mL})$, according to Van Soest (1994).

Values of $\mathrm{pH}$ between six and seven allow the presence of all components of the rumen microbial biomass, whether bacteria, fungi or protozoa (VAN SOEST, 1994). Thus, all $\mathrm{pH}$ values in this test were within the normal range (Table 7). 
Table 7. Concentrations of ammonia nitrogen $(\mathrm{mg} / 100 \mathrm{~mL})$ and ruminal fluid $\mathrm{pH}$, werum urea and total serum protein of lambs fed diets with increasing levels of cow cheese whey (SQB) in postprandial periods.

\begin{tabular}{|c|c|c|c|c|c|}
\hline \multicolumn{6}{|c|}{ Ammonia nitrogen $(\mathrm{mg} / 100 \mathrm{~mL})(\mathrm{CV}=29.67 \%)$} \\
\hline \multirow{2}{*}{ Time (hours) } & \multicolumn{4}{|c|}{ CCW inclusion (\% DM) } & \multirow{2}{*}{ Means } \\
\hline & 0 & 1.6 & 2.7 & 4.0 & \\
\hline 0 & 16.21 & 13.60 & 13.85 & 10.61 & $13.57^{\mathrm{B}}$ \\
\hline 3 & 16.77 & 19.36 & 20.36 & 13.44 & $17.48^{\mathrm{A}}$ \\
\hline 6 & 14.98 & 15.05 & 15.05 & 11.33 & $14.10^{\mathrm{B}}$ \\
\hline 9 & 18.10 & 15.60 & 18.52 & 14.76 & $16.74^{\mathrm{B}}$ \\
\hline Mean & $16.51^{\mathrm{a}}$ & $15.60^{\mathrm{a}}$ & $16.94^{\mathrm{a}}$ & $12.54^{\mathrm{b}}$ & - \\
\hline \multicolumn{6}{|c|}{ Ruminal fluid $p H(C V=6.75 \%)$} \\
\hline 0 & 6.87 & 7.00 & 6.87 & 7.44 & $7.05^{\mathrm{A}}$ \\
\hline 3 & 6.65 & 6.62 & 6.25 & 6.58 & $6.53^{\mathrm{B}}$ \\
\hline 6 & 6.10 & 6.11 & 6.25 & 6.94 & $6.35^{\mathrm{B}}$ \\
\hline 9 & 6.04 & 6.21 & 6.71 & 6.13 & $6.02^{\mathrm{C}}$ \\
\hline Mean & $6.41^{\mathrm{ab}}$ & $6.49^{\mathrm{ab}}$ & $6.27^{b}$ & $6.77^{\mathrm{a}}$ & - \\
\hline \multicolumn{6}{|c|}{ Serum urea $(\mathrm{mg} / 100 \mathrm{~mL})(\mathrm{CV}=28.63 \%)$} \\
\hline 0 & 50.73 & 46.62 & 46.36 & 41.12 & $46.21^{\mathrm{B}}$ \\
\hline 3 & 30.52 & 34.95 & 54.59 & 41.55 & $40.40^{\mathrm{B}}$ \\
\hline 6 & 29.56 & 26.68 & 38.99 & 35.51 & $32.68^{\mathrm{C}}$ \\
\hline 9 & 47.39 & 52.24 & 73.31 & 43.55 & $54.12^{\mathrm{A}}$ \\
\hline Mean & $39.55^{\mathrm{b}}$ & $40.12^{\mathrm{b}}$ & $53.31^{\mathrm{a}}$ & $40.43^{\mathrm{b}}$ & \\
\hline \multicolumn{6}{|c|}{ Total protein $(\mathrm{mg} / 100 \mathrm{~mL})(\mathrm{CV}=17.13 \%)$} \\
\hline 0 & 8.35 & 8.39 & 8.63 & 6.53 & $7.97^{\mathrm{AB}}$ \\
\hline 3 & 8.33 & 8.79 & 7.40 & 6.62 & $7.78^{\mathrm{B}}$ \\
\hline 6 & 7.20 & 8.62 & 9.95 & 8.39 & $8.54^{\mathrm{A}}$ \\
\hline 9 & 4.84 & 4.32 & 4.18 & 4.11 & $4.36^{\mathrm{C}}$ \\
\hline Mean & $7.18^{\mathrm{a}}$ & $7.53^{\mathrm{a}}$ & $7.54^{\mathrm{a}}$ & $6.41^{b}$ & \\
\hline
\end{tabular}

Mean values followed by different letters, in the same column, are significantly different by SNK test $(\mathrm{P}<0.05)$.

Mean values followed by different letters, in the same row, are significantly different by SNK test $(\mathrm{P}<0.05)$.

For the diet with $4.0 \% \mathrm{CCW}$, the $\mathrm{pH}$ was higher than with $2.7 \% \mathrm{CCW}$ inclusion. Within the times, it can be seen that at time zero there was a higher $\mathrm{pH}$ increase, being higher than the other times. The greatest decline in $\mathrm{pH}$ occurred at time 9, probably because $\mathrm{CCW}$ contains high levels of lactose and soluble proteins with a high fermentation rate, resulting in a greater amount of lactic acid from the fermentation of these nutrients.
There was an increase in urea levels nine hours after supplying the diets and in the diets with $2.7 \%$ inclusion of $\mathrm{CCW}$ (P $<0.05)$. Concentrations of serum urea can give an indication of ruminal protein availability and adequate protein supply in the diet, and values below normal can indicate deficiency in food or pathological states. Above normal values indicate pathological states, but can also indicate low efficiency in the use of ammonia available in the rumen due to a 
possible lack of fermentable energy. Nevertheless, urea levels were above the minimum required $(18 \mathrm{mg} / 100 \mathrm{~mL})$ and in some points higher than the maximum level $(31 \mathrm{mg} / 100 \mathrm{~mL})$, the greater release of urea in plasma may be an indication of smaller use of ammonia nitrogen released in the rumen for microbial protein synthesis (LIMA et al., 2012).

Serum levels of total proteins in this study were within the normal range (6.0 and $7.9 \mathrm{~g} / 100 \mathrm{~mL}$ ), except for time 9, which presented a lower concentration (VAN SOEST, 1994). The increased concentration of amino acids in the blood does not indicate improved protein nutrition of the animal, and the improvement in the balance of amino acids results in its decrease in the blood. After these nutritional, behavioral and blood evaluations, CCW was used in performance tests at Embrapa Goat and Sheep, showing a positive satisfactory effect as an excellent alternative for feeding finishing lambs (Rogério et al., 2017), with its use only dependent on availability in the local region of the production system. Interesting performances have also been proven in studies with CCW for goats (Leite et al., 2015) and in liquid diet in pre-slaughter management of sheep (Silva et al., 2018).

\section{CONCLUSIONS}

CCW has the potential to feed lambs because it does not interfere with nutrient intake and digestibility and promotes a positive nitrogen balance. It is indicated the inclusion of up to $4.0 \% \mathrm{DM}$ of CCW in the lambs diet.

\section{REFERENCES}

AOAC. Association of Official Analytical Chemists. Official Methods of Analysis of the Association of Official Analytical Chemistry. 18 ed. Washington DC: AOAC, 2010. 1115p.

ARAÚJO, A. R. Uso do soro de leite bovino na alimentação de caprinos. 2012. 39f. Dissertação (mestrado) Universidade Estadual Vale do Acaraú, Sobral.

CAPPELLE, E.R.; VALADARES FILHO, S.C.; COELHO DA SILVA, J.F.; CECON, P.R. Estimativas do valor energético a partir de características químicas e bromatológicas dos alimentos. Revista Brasileira de Zootecnia, v. 30, p. 1837-1856, 2001.

COSTA, R.G.; BELTRÃO FILHO, E.M.; MEDEIROS, G.R. et al. Substituição do leite de cabra por soro de queijo bovino para cabritos alpinos. Revista Brasileira de Zootecnia, v.39, n.4, p.824-830, 2010.

DAVID, FM.; COLLAO-SAENZ, E. A.; PÉREZ, J. R. O. et al. Efeito da adição de soro de leite sobre a digestibilidade aparente e os parâmetros sanguíneos de vacas secas. Arquivo Brasileiro de Medicina Veterinária e Zootecnia, v.62, n.5, p.1183-1190, 2010.

JOHNSON, T.R.; COMBS, D.K. Effects of prepartum diet, inert rumen bulk, and dietary polythyleneglicol on dry matter intake of lactating dairy cows. Journal of Dairy Science, 74:933-944, 1991.

LEITE, H.M.S.; ASSIS, A.P.P.; LIMA, R.N. et al. Desempenho e características de carcaça de cabritos superprecoce aleitados com soro de queijo associado 
ao leite bovino até os 60 dias. Acta

Veterinaria Brasilica, v.9, n.3, p.228233, 2015.

LIMA, R.N.; LIMA, P.O.; AROEIRA, L.J.M. et al. Desempenho de bezerros aleitados com soro de queijo em associação ao colostro. Pesquisa Agropecuária Brasileira, Brasília, v.47, n.8, p.1174-1180, 2012.

NRC -National Research Council. Nutrient requeriments of small ruminants. 1. ed. Washington, DC, USA: National Academy Press, 362p. 2007.

POLLI, V.A.; RESTLE, J.; SENNA, D. B.; ALMEIDA, S.R.S.Aspectos relativos à ruminação de bovinos $\mathrm{e}$ bubalinos em regime de confinamento. Revista Brasileira de Zootecnia, 25 (5):987-993, 1996.

PRAZERES, A. R.; CARVALHO, F; RIVAS, J. Cheese whey management: A review. Journal of Environmental Management, v. 110, p. 48-68, 15 nov. 2012.

ROGÉRIO, M.C.P; MARTINS, E.C.; BELCHIOR, L. S. et al. Soro de queijo tipo coalho de leite bovino: alternativa para a terminação de pequenos ruminantes no Semiárido nordestino. Comunicado técnico, 170, Sobral-CE: Embrapa, 2017.

SILVA, F.V.; BORGES, I.; SÁ, H.C.M. et al. Performance and carcass characteristics of lambs fed a solution of cheese whey during feedlot and preslaughter lairage. Revista Brasileira de Zootecnia, 47:e20170026, 2018.
VAN SOEST, P.J. Nutritional ecology of the ruminant. 2.ed. New York: Cornell University Press, 1994. 476p.

VAN SOEST, P.J.; ROBERTSON, J.B.; LEWIS, B.A. Methods for dietary fiber, neutral detergent fiber, and non-starch polysaccharides in relation to animal nutrition. Journal of Dairy Science, 74:3583-3597,1991.

WEISS, W.P. Energy prediction equations for ruminant feeds. In: CORNELL NUTRITION CONFERENCE FOR FEED MANUFACTURERS, 61, 1999, Proceedings..., Ithaca: Cornell University p.176-185,1999. 